Archives of Agriculture and Environmental Science

\title{
Growth analysis of short duration transplant Aus rice (Oryza sativa L. cv. Parija) under irrigated ecosystem
}

\author{
Bithi Roy and Swapan Kumar Paul \\ Department of Agronomy, Bangladesh Agricultural University, Mymensigh-2202, BANGLADESH \\ *Corresponding author's E-mail: skpaul@bau.edu.bd
}

\section{ARTICLE HISTORY}

Received: 01 February 2018

Revised received: 11 February 2018

Accepted: 26 February 2018

\section{Keywords}

Growth

Morpho-physiological

characteristics

Nitrogen

Spacing

Transplant Aus rice

\section{ABSTRACT}

An experiment was conducted at the Agronomy Field Laboratory, Bangladesh Agricultural University, Mymensingh during April to July 2012 to examine the effect of plant spacing and nitrogen level on the growth performance of short duration transplant Aus rice (cv. Parija) under irrigated ecosystem. The experiment comprised four plants spacings viz., $20 \mathrm{~cm} \times 20 \mathrm{~cm}, 20 \mathrm{~cm} \times$ $15 \mathrm{~cm}, 20 \mathrm{~cm} \times 10 \mathrm{~cm}$ and $15 \mathrm{~cm} \times 15 \mathrm{~cm}$ and four nitrogen levels viz. 0, 35, 70 and $105 \mathrm{~kg} \mathrm{~N} \mathrm{ha}^{-1}$. The experiment was laid out in a Randomized Complete Block Design with three replications. Morpho-physiological characters, of transplant Aus rice (cv. Parija) significantly influenced by spacing of planting, nitrogen level and their interaction. At 60 DAT, the highest plant height $\left(80.68 \mathrm{~cm}\right.$ ) was obtained at $20 \mathrm{~cm} \times 15 \mathrm{~cm}$ spacing fertilized with $70 \mathrm{~kg} \mathrm{~N} \mathrm{ha}^{-1}$ which was as good as $20 \mathrm{~cm} \times 10 \mathrm{~cm}$ fertilizad with $35 \mathrm{~kg} \mathrm{~N}^{-1}$. The maximum number of tillers hill ${ }^{-1}$ (15.16) was obtained at $20 \mathrm{~cm} \times 20 \mathrm{~cm}$ spacing fertilized with $105 \mathrm{~kg} \mathrm{~N}^{-1}$ which was statistically at par with $20 \mathrm{~cm} \times 15 \mathrm{cmfertilized} \mathrm{with} 70 \mathrm{~kg} \mathrm{~N} \mathrm{ha}^{-1}$. The highest total dry matter (8.92g) was obtained at the $20 \mathrm{~cm} \times 15 \mathrm{~cm}$ spacing fertilized with higher dose of nitrogen (105 kg N ha-1) and at 45-60 DAT, the highest crop growth rate (3.34) was obtained at $15 \mathrm{~cm} \times 15 \mathrm{~cm}$ spacing fertilized with $35 \mathrm{~kg} \mathrm{~N}^{-1}$ while the lowest CGR (1.12) was recorded at the same spacing $(15 \mathrm{~cm} \times 15 \mathrm{~cm}$ ) with control treatment. This study revealed that short duration transplant Aus rice cv. Parija can be cultivated at $20 \mathrm{~cm} \times 15 \mathrm{~cm}$ or $15 \mathrm{~cm} \times 15 \mathrm{~cm}$ spacing with 35 to $105 \mathrm{~kg} \mathrm{~N} \mathrm{ha}^{-1}$ for proper growth.

(C)2018 Agriculture and Environmental Science Academy

Citation of this article: Roy, B. and Paul, S.K. (2018). Growth analysis of short duration transplant Aus rice (Oryza sativa L. cv. Parija) under irrigated ecosystem. Archives of Agriculture and Environmental Science, 3(1): 68-72 DOI: 10.26832/24566632.2018.0301010

\section{INTRODUCTION}

Rice (Oryza sativa L.) is the most extensively cultivated crop in Bangladesh and the staple food for her people. In respect of area and production it ranks fourth among the rice producing countries of the world (FAO, 2009). There are three distinct growing seasons of rice namely, Aus, Aman and Boro in Bangladesh. Aus rice of the country covers an area of 1018623 ha with a production of 2288000 metric tons (BBS, 2016). Aus is the least productive season compared with other two seasons (BBS, 2016). Plant spacing is an important factor that needs to be considered in transplanted rice. The growth, yield and yield components of rice are also greatly influenced by plant spacing. Closer spacing hampered intercultural operation, more competition arises among the plant for nutrient, air and light as a result plant becomes weaker and thinner, consequently reduces dry matter accumulation and yield. Under wider plant spacing farmer could not get desired hill per unit area which ultimately reduces growth and as well as yield of rice. Proper spacing may help receive maximum light interceptions to enhance photosynthesis as like as growth and yield of rice (Jahan et al., 2017). Nitrogen is the most essential element in determining the growth and yield of rice production. Soil of Bangladesh is not properly enriched with different nutrients, especially nitrogen for growth and development of plant. Nitrogen is an essential macro element and it is being exhausted in many ways in the field. Plants growth is seriously hampered when lower dose of nitrogen is applied that hampered growth and drastically reduced yield (Ray et al., 2015). So, the selection of the most appropriate levels of nitrogen fertilizer is a major concern offering economic 
viability of the crop production. Therefore, the present study was conducted to find out the effect of plant spacing and nitrogen level on the growth performance of short duration transplant Aus rice (cv. Parija).

\section{MATERIALS AND METHODS}

\section{Study area and experimental design}

The experiment was conducted at the Agronomy Field Laboratory, Bangladesh Agricultural University, Mymensingh during the period from April to July 2012 to study the effect of spacing of planting and nitrogen level on the growth performance of short duration transplant Aus rice (cv. Parija) under irrigated ecosystem. This experiment was located at $24^{\circ} 75^{\prime} \mathrm{N}$ latitude and $90^{\circ} 50^{\prime} \mathrm{E}$ longitude having an altitude of $18 \mathrm{~m}$ above the mean sea level. The experimental site belongs to the Sonatala series of Old Brahmaputra Floodplain Agroecological Zone (AEZ -9) having non-calcareous dark grey floodplain soils (UNDP and FAO, 2009). The experiment field was medium high land having sandy loam with low organic matter content and $\mathrm{pH}$ 6.8. The experiment comprised four spacings viz., $20 \mathrm{~cm} \times 20 \mathrm{~cm}, 20 \mathrm{~cm} \times$ $15 \mathrm{~cm}, 20 \mathrm{~cm} \times 10 \mathrm{~cm}$ and $15 \mathrm{~cm} \times 15 \mathrm{~cm}$ and four nitrogen levels viz., 0, 35, 70 and $105 \mathrm{~kg} \mathrm{~N}^{-1}$. The experiment was laid out in a Randomized Complete Block Design with three replications. The net size of each unit plot was $4.0 \mathrm{~m} \times 2.5 \mathrm{~m}$.

\section{Selection of rice variety and preparation of nursery}

A short duration local variety of Aus rice cv. Parija was used in this experiment. The sprouted seeds were broadcasted uniformly in a well prepared nursery bed on 15 April, 2012. The land was first opened with a tractor driven plough, ploughing followed by laddering were done with a country plough and a ladder. Weeds and stubbles were removed from the field as much as possible after leveling. The lands were finally prepared and the plots were laid out on 4 May, 2012. In addition to nitrogen a basal dose each of triple super phosphate, muriate of potash, gypsum and zinc sulphate at the rate of $90,60,38$ and $8 \mathrm{~kg} \mathrm{ha}^{-1}$, respectively were applied in all plots. Nitrogen fertilizer in the form of urea was applied as per treatment used in the experiment in two equal splits at 10 DAT and 30 DAT. All the plots were transplanted on 5 May, 2012 using 3-4 seedlings hill ${ }^{-1}$. Constant water depth of 5 $-7 \mathrm{~cm}$ was maintained in the experimental field throughout the growing period. The experimental plots were irrigated and drained out as and when necessary during the growing period of the crop. The crops was found infested with some weeds and were controlled by hand weeding. To control insects, $10 \mathrm{~kg}$ of granular Carbofuran-5G per hectare were applied during the first top-dressed of urea; liquid insecticides were applied during the second top-dress and during the milking stage of the panicle to save the crop from stem borer and rice bug insects.

\section{Determination of plant parameters}

Growth parameter such as plant height, no of tillers hill ${ }^{-1}$, total dry matter production hill $^{-1}$ etc. were determined at 15, 30, 45 and 60 DAT. Five hills were marked by bamboo stick excluding boarder rows to collect data on plant height and tiller number. Plant height was measured with the tallest tiller from the selected hills which gave average plant height.

To determine total dry matter, four hills were taken from the outside of harvest area and excluding boarder rows at 15,30, 45 and 60 DAT. The roots of each plant were removed, then the plants were washed with tap water and the destructive plant samples were packed in labeled brown paper bags and dried in the oven at $85 \pm 5^{\circ} \mathrm{c}$ for 72 hours until constant weight was reached. The samples were weighed carefully after oven drying to measure the dry weight of plant.

Crop growth rate (CGR): Increase of materials per unit of time.

$$
\mathrm{CGR}=\frac{1}{\mathrm{~A}} \times \frac{\mathrm{W}_{2}-\mathrm{W}_{1}}{\mathrm{~T}_{2}-\mathrm{T}_{1}}\left(\mathrm{mg} \text { day }^{-1} \text { hill }^{-1}\right)
$$

\section{Statistical analysis of data}

Recorded data were analyzed statistically using analysis of variance (ANOVA) technique and the differences among treatment means were adjudged by Duncan's Multiple Range Test (DMRT) (Gomez and Gomez, 1984).

\section{RESULTS AND DISCUSSION}

\section{Plant height}

The height of the plant was significantly affected by plant spacing (Table 1). At 15 days after transplanting (DAT) the tallest plant $(25.62 \mathrm{~cm})$ was obtained at plant spacing $20 \mathrm{~cm} \times 10$ $\mathrm{cm}$ which was statistically identical to $20 \mathrm{~cm} \times 15 \mathrm{~cm}$ plant spacing $(25.41 \mathrm{~cm})$ and the shortest one $(20.75 \mathrm{~cm})$ was obtained at widest spacing $20 \mathrm{~cm} \times 20 \mathrm{~cm}$. The tallest plant $(46.83 \mathrm{~cm})$ was obtained at widest spacing $20 \mathrm{~cm} \times 20 \mathrm{~cm}$ which was statistically identical to $20 \mathrm{~cm} \times 15 \mathrm{~cm}$ plant spacing at 30 DAT and the lowest one $(40.34 \mathrm{~cm})$ was obtained at closest spacing $15 \mathrm{~cm} \times$ $15 \mathrm{~cm}$. At 45 DAT, the tallest plant height $(66.35 \mathrm{~cm})$ was obtained at widest plant spacing $20 \mathrm{~cm} \times 20 \mathrm{~cm}$ and the lowest one $(60.79 \mathrm{~cm})$ was obtained at closest spacing $15 \mathrm{~cm} \times 15 \mathrm{~cm}$. At 60 DAT, the tallest plant height $(78.31 \mathrm{~cm})$ was obtained at plant spacing $20 \mathrm{~cm} \times 10 \mathrm{~cm}$ and the lowest one $(78.31 \mathrm{~cm}$ ) was obtained at plant spacing $15 \mathrm{~cm} \times 15 \mathrm{~cm}$. Plant height of transplant Aus rice increased with increased growth duration up to 60 DAT (Table 1). Remarkable differences among different levels of nitrogen were found at all dates of sampling. The tallest plant was obtained when fertilized with $105 \mathrm{~kg} \mathrm{~N}^{-1}$ and the lowest one recorded in control at all sampling. Plant height increased due to application of nitrogen was reported elsewhere (Salahuddin et al, 2009 and Kirtannia et al., 2013). The interaction effect of different plant spacing and nitrogen levels had significant effect on plant height (Table 2). At 15 DAT, the highest plant height $(27.23 \mathrm{~cm})$ was obtained at the spacing $20 \mathrm{~cm} \times 10 \mathrm{~cm}$ with $105 \mathrm{~kg} \mathrm{~N} \mathrm{ha}^{-1}$ and the lowest plant height 
$(18.81 \mathrm{~cm})$ was obtained at the widest spacing $(20 \mathrm{~cm} \times 20 \mathrm{~cm})$ with control treatment. The interaction of different spacing and nitrogen levels did not produce any significant effect on plant height at 30 DAT. At 45 DAT, the highest plant height was obtained at the widest spacing $(20 \mathrm{~cm} \times 20 \mathrm{~cm})$ with $105 \mathrm{~kg} \mathrm{~N} \mathrm{ha}^{-1}$ and the lowest one $(69.46 \mathrm{~cm})$ was obtained at spacing $20 \mathrm{~cm} \times$ $20 \mathrm{~cm}$ with control application. At 60 DAT, the highest plant height $(80.68 \mathrm{~cm})$ was obtained at spacing $20 \mathrm{~cm} \times 15 \mathrm{~cm}$ fertilized with $70 \mathrm{~kg} \mathrm{~N} \mathrm{ha}^{-1}$ and the lowest plant height $(68.69 \mathrm{~cm})$ was obtained at closest spacing $(15 \mathrm{~cm} \times 15 \mathrm{~cm})$ with control nitrogen.

\section{Tillering pattern}

Spacing had significant effect on the number of tillers hill ${ }^{-1}$ (Table 1). At 15 DAT, the maximum number of tillers hill ${ }^{-1}(4.84)$ was observed at spacing $20 \mathrm{~cm} \times 10 \mathrm{~cm}$ and the minimum one (4.37) was observed at spacing $15 \mathrm{~cm} \times 15 \mathrm{~cm}$. At 30 DAT, the maximum number of tillers hill ${ }^{-1}$ was obtained at the widest spacing $20 \mathrm{~cm} \times 20 \mathrm{~cm}$ which was statistically identical to spacing $20 \mathrm{~cm} \times 15 \mathrm{~cm}$ and $20 \mathrm{~cm} \times 10 \mathrm{~cm}$ while the minimum number of tillers hill ${ }^{-1}(6.46)$ was obtained at the closest spacing (15 $\mathrm{cm} \times 15 \mathrm{~cm})$. At $45 \mathrm{DAT}$, the maximum number of tillers hill ${ }^{-1}$ (11.72)was observed at widest spacing $20 \mathrm{~cm} \times 20 \mathrm{~cm}$ and the minimum number of tillers hill ${ }^{-1}$ (9.00) obtained at the closest spacing $(15 \mathrm{~cm} \times 15 \mathrm{~cm})$. At 60 DAT, the maximum number of tillers hill ${ }^{-1}$ (12.89) was observed at the spacing $20 \mathrm{~cm} \times 15 \mathrm{~cm}$ and the minimum number of tillers hill ${ }^{-1}(9.88)$ was obtained at the closest spacing $(15 \mathrm{~cm} \times 15 \mathrm{~cm})$. The reason might be wide spaced plants received more nutrients; moisture and light thus produced higher number of tillers hill ${ }^{-1}$. Wider spacing produced maximum number of total tillers than closer spacing in rice was reported elsewhere (Mobasser et al., 2007 and Ray et al., 2015). Tillering pattern of transplant Aus rice (cv. Parija) at different spacing over time were gradually increased by gradual elevation of nitrogen fertilizer. Maximum tillers hill ${ }^{-1}$ (13.89) was produced at 60 DAT (Table 3). Number of tillers increased with increased levels of nitrogen and highest number of tillers were obtained when $105 \mathrm{~kg} \mathrm{~N} \mathrm{ha}^{-1}$ was applied and lowest from control treatment at all sampling dates. Similar result was observed from the findings of Sharma and Mishra (1986).The interaction effect between plant spacing and nitrogen levels was found to be significant at 30 and 60 DAT but insignificant at 15 and 45 DAT (Table 2). The maximum number of tillers hill ${ }^{-1}(10.98)$ and (15.16) was obtained at the widest spacing $(20 \mathrm{~cm} \times 20 \mathrm{~cm})$ fertilized with $105 \mathrm{~kg} \mathrm{~N} \mathrm{ha}^{-1}$ and the minimum number of tillers hill ${ }^{-1}(4.23)$ and (6.95) was obtained at the closest spacing $(15 \mathrm{~cm} \times 15 \mathrm{~cm})$ with control treatment at 30 DAT and 60 DAT. The growth stage effect was pronounced by decreasing number of tillers hill ${ }^{-1}$ during flowering stage and post flowering stage might be due to senescence of tillers at later stages of growth. The significantly highest tillers was obtained by $20 \mathrm{~cm} \times 20 \mathrm{~cm}$ plant spacing fertilized with $105 \mathrm{~kg} \mathrm{~N} \mathrm{ha}^{-1}$. The lowest number of tillers hill ${ }^{-1}$ was found always by the control treatment with closest spacing.
Total dry matter (TDM) production

Significant effect of spacing on total dry matter production hill $^{-1}$ was observed at 15, 30, 45 and 60 DAT (Table 3). The highest TDM hill ${ }^{-1}$ was obtained at $20 \mathrm{~cm} \times 15 \mathrm{~cm}$ plant spacing at all sampling dates. The lowest TDM hill ${ }^{-1}$ was obtained the closest spacing $(15 \mathrm{~cm} \times 15 \mathrm{~cm})$ at 60 DAT. The lowest TDM hill' ${ }^{1}$ was obtained at the spacing $20 \mathrm{~cm} \times 10 \mathrm{~cm}$ at 15,30 and 45 DAT. The result was agreement with that of Murty and Murty (1980). Tyeb et al. (2013) reported that rice crop produced higher dry matter when transplanted at $25 \mathrm{~cm} \times 15 \mathrm{~cm}$ spacing the value decreased when transplanted in $20 \mathrm{~cm} \times 10 \mathrm{~cm}$ plant spacing. Nitrogen levels had significant effect on the production of total dry matter (TDM) hill ${ }^{-1}$ (Table 3). Total dry matter production by plants increased progressively with the advancement of growth stages of transplant Aus rice and it was also increased gradually with increased levels of nitrogen up to $70 \mathrm{~kg} \mathrm{~N} \mathrm{ha}^{-1}$ and declined thereafter. The highest TDM hill ${ }^{-1}$ was obtained when $70 \mathrm{~kg} \mathrm{~N}^{-1}$ was applied and the lowest one was obtained when fertilized with $35 \mathrm{~kg} \mathrm{~N} \mathrm{ha}^{-1}$ at all sampling dates but at $60 \mathrm{DAT}$, the lowest TDM (5.63) hill ${ }^{-1}$ was obtained with control application of $\mathrm{N}$. Total dry matter production hill $^{-1}$ increased due to application of higher dose of nitrogen (Ray et al., 2015) where application of $80 \mathrm{~kg} \mathrm{~N}^{-1} \mathrm{~h}^{-1}$ produced higher dry matter hill ${ }^{-1}$.The interaction effect between plant spacing and nitrogen levels was significant at 60 DAT but insignificant at 15, 30 and 45 DAT (Table 4). The highest total dry matter (8.92) was observed at the spacing $20 \mathrm{~cm} \times 15 \mathrm{~cm}$ fertilized with higher dose of nitrogen $105 \mathrm{~kg} \mathrm{~N} \mathrm{ha}^{-1}$ and the lowest one (1.12) was found at the closest spacing $(15 \mathrm{~cm} \times 15 \mathrm{~cm})$ with control application of nitrogen at 60 DAT.

\section{Crop growth rate (CGR)}

The effect of plant spacing in different crop growth rate (CGR) was significant at 15-30 DAT and 45-60 DAT but not in 30-45 DAT. At 45-60 DAT, the highest CGR (2.68) was obtained at the spacing $20 \mathrm{~cm} \times 10 \mathrm{~cm}$ and the lowest CGR (2.01) was obtained at the wider spacing $(20 \mathrm{~cm} \times 20 \mathrm{~cm}$ ) (Table 3). Plant spacing influenced the CGR at various growth stage of rice (Tyeb et al., 2013). The effect of nitrogen level in different crop growth rate (CGR) was significant at (45-60) DAT but not in (15-30) DAT and (30-45) DAT (Table 3). At 45-60 DAT, the highest CGR (2.56) was obtained when fertilized with $35 \mathrm{~kg} \mathrm{~N} \mathrm{ha}^{-1}$ and the lowest one (1.86) obtained with control application. Ray et al. (2015) reported that CGR varied due to rate of nitrogen application. The interaction effect between plant spacing and nitrogen levels was significant at 15-30 DAT and 45-60 DAT but not significant at 30-45 DAT (Table 4). At 15-30 DAT, the highest CGR (1.34) was found at the widest spacing $(20 \mathrm{~cm} \times 20 \mathrm{~cm})$ with control application and the lowest CGR (0.56) was found at the closest spacing $(15 \mathrm{~cm} \times 15 \mathrm{~cm})$ with control application. At 45 60 DAT, The highest CGR (3.34) was obtained at the closest spacing $(15 \mathrm{~cm} \times 15 \mathrm{~cm})$ fertilized with $35 \mathrm{~kg} \mathrm{~N}^{-1}$ and the lowest CGR (1.12) was obtained at $15 \mathrm{~cm} \times 15 \mathrm{~cm}$ with control application. 
Table 1. Effect of plant spacing and level of nitrogen on plant height and number of tillers hill ${ }^{-1}$ at different days after transplanting.

\begin{tabular}{|c|c|c|c|c|c|c|c|c|}
\hline & \multicolumn{4}{|c|}{ Plant height $(\mathrm{cm})$} & \multicolumn{4}{|c|}{ Number of tillers hill ${ }^{-1}$} \\
\hline & 15 DAT & 30 DAT & 45 DAT & 60 DAT & 15 DAT & 30 DAT & 45 DAT & 60 DAT \\
\hline \multicolumn{9}{|c|}{ Plant spacing $(\mathrm{cm} \times \mathrm{cm})$} \\
\hline $20 \mathrm{~cm} \times 20 \mathrm{~cm}$ & $20.75 c$ & $46.83 a$ & $66.35 a$ & $76.71 b$ & $4.62 a b$ & $8.25 a$ & $11.72 a$ & $12.80 a$ \\
\hline $20 \mathrm{~cm} \times 15 \mathrm{~cm}$ & $25.41 a$ & $46.40 a$ & $64.29 b$ & $75.91 b$ & 4.53ab & $8.01 a$ & $10.87 b$ & $12.89 a$ \\
\hline $20 \mathrm{~cm} \times 10 \mathrm{~cm}$ & $25.62 a$ & 41.01b & $62.79 c$ & $78.31 a$ & $4.84 a$ & $7.67 a$ & $10.28 b$ & $10.80 b$ \\
\hline $15 \mathrm{~cm} \times 15 \mathrm{~cm}$ & $24.16 b$ & $40.34 b$ & $60.79 d$ & $69.58 c$ & $4.37 b$ & $6.46 b$ & $9.00 c$ & $9.88 c$ \\
\hline$C V(\%)$ & 4.45 & 3.17 & 2.49 & 2.01 & 8.61 & 11.9 & 7.93 & 8.12 \\
\hline Level of sig. & $*$ & $* *$ & $* *$ & $* *$ & $*$ & $* *$ & $* *$ & $* *$ \\
\hline \multicolumn{9}{|c|}{ Nitrogen level $\left(\mathrm{kg} \mathrm{ha}^{-1}\right)$} \\
\hline 0 & $22.82 b$ & $42.56 b$ & $60.89 b$ & $72.01 \mathrm{c}$ & $4.21 c$ & $5.86 c$ & $8.74 c$ & $8.43 d$ \\
\hline 35 & $24.07 a$ & $43.83 a$ & $64.34 a$ & $74.68 \mathrm{~b}$ & $4.50 b c$ & $7.81 \mathrm{~b}$ & $10.07 b$ & $11.42 c$ \\
\hline 70 & $24.38 a$ & $43.93 a$ & $63.88 a$ & $76.86 a$ & 4.70ab & $7.69 \mathrm{~b}$ & $11.22 \mathrm{a}$ & $12.63 b$ \\
\hline 105 & $24.66 a$ & $44.26 a$ & $65.13 a$ & $76.96 a$ & $4.96 a$ & $9.02 a$ & $11.84 a$ & $13.89 a$ \\
\hline $\mathrm{CV}(\%)$ & 4.45 & 3.17 & 2.49 & 2.01 & 8.61 & 11.9 & 7.93 & 8.12 \\
\hline Level of sig. & $* *$ & * & $* *$ & $* *$ & $* *$ & $* *$ & $* *$ & $* *$ \\
\hline
\end{tabular}

Mean values in a column having the same letter do not differ significantly as per DMRT; DAT- Days after transplanting; ${ }^{* *}$ Significant at $1 \%$ level, ${ }^{*}$ Significant at $5 \%$ level.

Table 2. Interaction effect of spacing of planting and nitrogen levels on plant height and number of total tillers hill ${ }^{-1}$ at different days after transplanting.

\begin{tabular}{|c|c|c|c|c|c|c|c|c|}
\hline \multirow{2}{*}{$\begin{array}{l}\text { Interaction } \\
\text { (Plant spacing } \times \mathrm{N} \text { level) }\end{array}$} & \multicolumn{4}{|c|}{ Plant height } & \multicolumn{4}{|c|}{ Number of tillers hill ${ }^{-1}$} \\
\hline & 15 DAT & 30 DAT & 45 DAT & 60 DAT & 15 DAT & 30 DAT & 45 DAT & 60 DAT \\
\hline $\mathrm{S}_{1} \times \mathrm{N}_{0}$ & $18.81 \mathrm{f}$ & 45.76 & $60.38 f$ & $74.81 d$ & 4.14 & $5.80 f$ & 9.40 & $8.76 \mathrm{~h}$ \\
\hline $\mathrm{S}_{1} \times \mathrm{N}_{1}$ & $20.95 e$ & 45.97 & 66.96ab & $76.14 \mathrm{~cd}$ & 4.53 & 7.00def & 11.72 & $12.68 \mathrm{de}$ \\
\hline $\mathrm{S}_{1} \times \mathrm{N}_{2}$ & $20.96 \mathrm{e}$ & 47.29 & $68.61 \mathrm{a}$ & $77.29 \mathrm{bcd}$ & 4.70 & $9.20 b c$ & 12.60 & 14.59abc \\
\hline $\mathrm{S}_{1} \times \mathrm{N}_{3}$ & $22.26 \mathrm{de}$ & 48.28 & $69.46 a$ & 78.59abc & 5.12 & $10.98 a$ & 13.15 & $15.16 a$ \\
\hline $\mathrm{S}_{2} \times \mathrm{N}_{0}$ & $24.77 b c$ & 44.23 & 63.47cde & $68.75 \mathrm{e}$ & 4.11 & $6.34 \mathrm{ef}$ & 9.32 & $9.30 \mathrm{gh}$ \\
\hline $\mathrm{S}_{2} \times \mathrm{N}_{1}$ & 26.34ab & 46.59 & $64.89 \mathrm{bc}$ & $76.10 \mathrm{~cd}$ & 4.48 & 10.30ab & 10.48 & $13.21 \mathrm{bcd}$ \\
\hline $\mathrm{S}_{2} \times \mathrm{N}_{2}$ & 25.31abc & 46.45 & $64.63 b c$ & $78.12 \mathrm{abc}$ & 4.62 & 7.30def & 11.52 & $14.22 \mathrm{a}-\mathrm{d}$ \\
\hline $\mathrm{S}_{2} \times \mathrm{N}_{3}$ & $25.22 b c$ & 48.34 & $64.18 \mathrm{bcd}$ & $80.68 a$ & 4.92 & $8.10 \mathrm{~cd}$ & 12.15 & 14.82ab \\
\hline $\mathrm{S}_{3} \times \mathrm{N}_{0}$ & $23.46 \mathrm{~cd}$ & 40.97 & $63.10 c-f$ & $75.80 \mathrm{~cd}$ & 4.38 & $7.05 \mathrm{def}$ & 8.17 & $8.69 \mathrm{~h}$ \\
\hline $\mathrm{S}_{3} \times \mathrm{N}_{1}$ & $25.34 a b c$ & 41.82 & $63.35 c-f$ & $77.29 \mathrm{bcd}$ & 4.73 & 6.95def & 9.80 & $10.51 \mathrm{fg}$ \\
\hline $\mathrm{S}_{3} \times \mathrm{N}_{2}$ & $26.43 a b$ & 40.78 & 61.38def & $80.67 a$ & 5.07 & 7.27def & 11.25 & 11.12ef \\
\hline $\mathrm{S}_{3} \times \mathrm{N}_{3}$ & $27.23 a$ & 40.47 & $63.34 c-f$ & 79.48ab & 5.19 & $9.39 \mathrm{bc}$ & 11.88 & $12.89 \mathrm{~cd}$ \\
\hline $\mathrm{S}_{4} \times \mathrm{N}_{0}$ & $24.23 c$ & 39.28 & $56.60 \mathrm{~g}$ & $68.69 \mathrm{e}$ & 4.20 & $4.23 \mathrm{~g}$ & 8.06 & $6.95 i$ \\
\hline $\mathrm{S}_{4} \times \mathrm{N}_{1}$ & $23.64 \mathrm{~cd}$ & 40.95 & $62.14 c-f$ & $69.20 \mathrm{e}$ & 4.27 & 7.00def & 8.27 & $9.27 \mathrm{gh}$ \\
\hline $\mathrm{S}_{4} \times \mathrm{N}_{2}$ & $24.83 b c$ & 41.18 & $60.91 \mathrm{ef}$ & $71.35 \mathrm{e}$ & 4.39 & 7.00def & 9.51 & $10.58 \mathrm{fg}$ \\
\hline $\mathrm{S}_{4} \times \mathrm{N}_{3}$ & $23.93 \mathrm{~cd}$ & 39.94 & $63.53 \mathrm{cde}$ & $69.10 \mathrm{e}$ & 4.62 & 7.60de & 10.17 & 12.70de \\
\hline$C V(\%)$ & 4.45 & 3.17 & 2.49 & 2.01 & 8.61 & 11.9 & 7.93 & 8.12 \\
\hline Level of significance & $*$ & NS & $* *$ & $* *$ & NS & $* *$ & NS & * \\
\hline
\end{tabular}

Mean values in a column having the same letter do not differ significantly as per DMRT; ${ }^{* *}$ Significant at $1 \%$ level, ${ }^{*}$ significant at $5 \%$ level, NS- Not significant.

Table 3. Effect of plant spacing and level of nitrogen on total dry matter production and crop growth rate at different days after transplanting.

\begin{tabular}{|c|c|c|c|c|c|c|c|}
\hline & \multicolumn{4}{|c|}{ Total dry matter ( $\mathrm{g} \mathrm{hill}^{-1}$ ) } & \multicolumn{3}{|c|}{ Crop growth rate (CGR) } \\
\hline & 15 DAT & 30 DAT & 45 DAT & 60 DAT & $15-30$ & $30-45$ & $45-60$ \\
\hline \multicolumn{8}{|c|}{ Plant spacing $(\mathrm{cm} \times \mathrm{cm})$} \\
\hline $20 \mathrm{~cm} \times 20 \mathrm{~cm}$ & $1.74 b$ & $3.34 a$ & $4.33 a$ & $7.34 b$ & $1.07 a$ & 0.66 & $2.01 \mathrm{c}$ \\
\hline $20 \mathrm{~cm} \times 15 \mathrm{~cm}$ & $1.97 a$ & $3.49 a$ & $4.47 a$ & $8.10 a$ & $1.02 \mathrm{ab}$ & 0.65 & $2.42 a b$ \\
\hline $20 \mathrm{~cm} \times 10 \mathrm{~cm}$ & $1.17 \mathrm{c}$ & $2.39 \mathrm{~b}$ & $3.41 b$ & $7.42 b$ & $0.81 b$ & 0.68 & $2.68 a$ \\
\hline $15 \mathrm{~cm} \times 15 \mathrm{~cm}$ & $1.30 c$ & $2.51 \mathrm{~b}$ & $3.43 b$ & $6.68 c$ & $0.81 b$ & 0.61 & $2.16 \mathrm{bc}$ \\
\hline $\mathrm{CV}(\%)$ & 14.26 & 11.9 & 9.31 & 7.32 & 9.03 & 12.53 & 8.07 \\
\hline Level of sig. & $* *$ & $* *$ & $* *$ & $* *$ & $*$ & NS & $* *$ \\
\hline \multicolumn{8}{|c|}{ Nitrogen level $\left(\mathrm{kg} \mathrm{ha}^{-1}\right)$} \\
\hline 0 & $1.33 b$ & $2.72 \mathrm{~b}$ & $3.67 \mathrm{~b}$ & $6.46 c$ & $1.07 a$ & 0.66 & $2.01 \mathrm{c}$ \\
\hline 35 & $1.10 c$ & $2.42 c$ & $3.35 c$ & $7.19 \mathrm{~b}$ & $1.02 a b$ & 0.65 & $2.42 a b$ \\
\hline 70 & $1.91 \mathrm{a}$ & $3.34 a$ & $4.35 a$ & $8.08 a$ & $0.81 b$ & 0.68 & $2.68 a$ \\
\hline 105 & $1.84 a$ & $3.27 a$ & $4.27 a$ & $7.83 a$ & $0.81 b$ & 0.61 & $2.16 \mathrm{bc}$ \\
\hline $\mathrm{CV}(\%)$ & 14.26 & 11.9 & 9.31 & 7.32 & 9.03 & 12.53 & 8.07 \\
\hline Level of sig. & $* *$ & $* *$ & $* *$ & $* *$ & $*$ & NS & $* *$ \\
\hline
\end{tabular}


Table 4. Interaction effect of spacing of planting and nitrogen levels on total dry matter production and crop growth rate at different days after transplanting.

\begin{tabular}{|c|c|c|c|c|c|c|c|}
\hline \multirow{2}{*}{ Interaction } & \multicolumn{4}{|c|}{ Total dry matter (g hill ${ }^{-1}$ ) } & \multicolumn{3}{|c|}{ Crop growth rate (CGR) } \\
\hline & 15 DAT & $30 \mathrm{DAT}$ & 45 DAT & 60 DAT & $15-30$ & $30-45$ & $45-60$ \\
\hline $\mathrm{S}_{1} \times \mathrm{N}_{0}$ & 1.40 & 3.42 & 4.44 & $6.65 f g$ & $1.34 a$ & 0.68 & $1.47 \mathrm{fg}$ \\
\hline $\mathrm{S}_{1} \times \mathrm{N}_{1}$ & 1.27 & 3.03 & 3.98 & $7.36 c-f$ & 1.17abc & 0.63 & $2.25 b-f$ \\
\hline $\mathrm{S}_{1} \times \mathrm{N}_{2}$ & 2.22 & 3.52 & 4.47 & $8.12 a-d$ & $0.86 a-d$ & 0.64 & 2.43b-e \\
\hline $\mathrm{S}_{1} \times \mathrm{N}_{3}$ & 2.07 & 3.40 & 4.42 & $7.24 c-f$ & $0.89 a-d$ & 0.68 & $1.88 \mathrm{ef}$ \\
\hline $\mathrm{S}_{2} \times \mathrm{N}_{0}$ & 1.77 & 3.00 & 3.98 & 7.07ef & $0.82 \mathrm{bcd}$ & 0.65 & $2.06 c-f$ \\
\hline $\mathrm{S}_{2} \times \mathrm{N}_{1}$ & 1.47 & 2.64 & 3.53 & $7.61 c-f$ & $0.78 \mathrm{bcd}$ & 0.60 & $2.72 a-d$ \\
\hline $\mathrm{S}_{2} \times \mathrm{N}_{2}$ & 2.33 & 4.26 & 5.34 & 8.80ab & 1.29ab & 0.72 & 2.31b-e \\
\hline $\mathrm{S}_{2} \times \mathrm{N}_{3}$ & 2.30 & 4.07 & 5.04 & $8.92 a$ & 1.18abc & 0.65 & 2.58a-e \\
\hline $\mathrm{S}_{3} \times \mathrm{N}_{0}$ & 0.73 & 2.21 & 3.16 & $7.32 c-f$ & $0.98 a-d$ & 0.64 & 2.77abc \\
\hline $\mathrm{S}_{3} \times \mathrm{N}_{1}$ & 0.82 & 2.03 & 3.03 & $5.90 \mathrm{~g}$ & $0.80 \mathrm{bcd}$ & 0.67 & 1.91def \\
\hline $\mathrm{S}_{3} \times \mathrm{N}_{2}$ & 1.55 & 2.64 & 3.64 & 8.18a-d & $0.73 c d$ & 0.67 & $3.03 a b$ \\
\hline $\mathrm{S}_{3} \times \mathrm{N}_{3}$ & 1.59 & 2.68 & 3.78 & 8.27abc & $0.72 \mathrm{~cd}$ & 0.74 & 2.99ab \\
\hline $\mathrm{S}_{4} \times \mathrm{N}_{0}$ & 1.40 & 2.24 & 3.11 & $4.79 \mathrm{~h}$ & $0.56 \mathrm{~d}$ & 0.58 & $1.12 \mathrm{~g}$ \\
\hline $\mathrm{S}_{4} \times \mathrm{N}_{1}$ & 0.85 & 1.97 & 2.86 & 7.87b-e & $0.75 c d$ & 0.60 & $3.34 a$ \\
\hline $\mathrm{S}_{4} \times \mathrm{N}_{2}$ & 1.54 & 2.92 & 3.94 & 7.19def & $0.92 a-d$ & 0.68 & $2.17 c-f$ \\
\hline $\mathrm{S}_{4} \times \mathrm{N}_{3}$ & 1.41 & 2.93 & 3.83 & 6.87ef & $1.01 \mathrm{a}-\mathrm{d}$ & 0.60 & $2.03 c-f$ \\
\hline$C V(\%)$ & 14.26 & 11.9 & 9.31 & 7.32 & 9.03 & 12.53 & 8.07 \\
\hline Level of sig. & NS & NS & NS & $* *$ & $*$ & NS & $* *$ \\
\hline
\end{tabular}

Mean values in a column having the same letter do not differ significantly as per DMRT; ${ }^{* *}$ significant at $1 \%$ level, ${ }^{*}$ significant at $5 \%$ level, NS Not significant.

\section{Conclusion}

The present investigation concluded that the highest plant height was obtained at $20 \mathrm{~cm} \times 15 \mathrm{~cm}$ spacing fertilized with 70 $\mathrm{kg} \mathrm{N} \mathrm{ha}^{-1}$ while the maximum number of tillers hill ${ }^{-1}$ was obtained at $20 \mathrm{~cm} \times 20 \mathrm{~cm}$ spacing when fertilized with $105 \mathrm{~kg} \mathrm{~N} \mathrm{ha}^{-1}$. The highest total dry matter production hill ${ }^{-1}$ was obtained at the 20 $\mathrm{cm} \times 15 \mathrm{~cm}$ spacing fertilized with higher dose of nitrogen (105 $\mathrm{kg} \mathrm{N} \mathrm{ha}^{-1}$ ) and at 45-60 DAT, the highest crop growth rate was obtained at $15 \mathrm{~cm} \times 15 \mathrm{~cm}$ spacing fertilized with $35 \mathrm{~kg} \mathrm{~N} \mathrm{ha}^{-1}$ while the lowest CGRwas recorded at the same spacing $(15 \mathrm{~cm} \times$ $15 \mathrm{~cm}$ ) with control nitrogen. Therefore, short duration transplant Aus rice cv. Parija can be cultivated at $20 \mathrm{~cm} \times 15 \mathrm{~cm}$ or 15 $\mathrm{cm} \times 15 \mathrm{~cm}$ planting spacing with 35 to $105 \mathrm{~kg} \mathrm{~N} \mathrm{ha}^{-1}$ for proper growth.

Open Access: This is open access article distributed under the terms of the Creative Commons Attribution License, which permits unrestricted use, distribution, and reproduction in any medium, provided the original author(s) and the source are credited.

\section{REFERENCES}

BBS. (2016). Year Book Agricultural Statistics, Ministry of planning, Government People's Republic of Bangladesh, Dhaka, pp. 17- 49.

FAO. (2009). Production Year Book. Food and Agric. Organ of the United Nations, Rome. 45: 72-73.

Gomez, K.A. and Gomez, A.A. (1984). Statistical Procedures for Agricultural Research. Int. Rice Res. Inst., John Wiley and Sons. New York, Chichester, Brisbane, Toronto,, Singapore, pp. 680 .

Jahan, S., Sarkar, M.A.R. and Paul, S.K. (2017). Variations of growth parameters in transplanted Aman rice (cv. BRRI dhan39) in response to plant spacing and fertilizer management. Archives of Agriculture and Environmental Science, 2 (1): 1-5.

Kirtannia, B., Sarkar, M.A.R, Paul, S.K. and Islam, M.S. (2013). Morpho-physiological attributes of transplant Aman rice as influenced by variety, age of tiller seedlings and nitrogen management. Journal of Agroforestry and Environment, 7 (2):149-154.

Mobasser, H.R., Tari, D.B., Vojdani, M., Abadi, R. and Eftekhar, A. (2007). Effect of seedling age and planting space on yield and yield components of rice (cv. Neda). Asian Journal Plant Sciences, 6(2): 438-440.

Murty, P.S.S. and Murty, M. (1980). Effect of spacing on the physiological attributes of two high yielding long duration rice cultivars. Oryza, 17(2):148-150.

Ray, S., Sarkar, M.A.R., Paul, S.K., Islam, A.K.M.M. and Yeasmin, S. (2015). Variation of growth, yield and protein content of transplant Aman rice by three agronomic practices. Agricultural and Biological Sciences Journal, 1 (4): 167-176.

Salahuddin K.M., Chowhdury, S.H., Munira, S., Islam, M.M. and Parvin, S. (2009). Response of nitrogen and plant spacing of transplanted Aman rice. Bangladesh Journal of Agricultural Research, 34(2): 279-285.

Sharma, A.L. and Mishra, V.R. (1986). Effect of fertilizer nitrogen and algal inoculation on rice corp. Madras Agriculture Journal, 71(2): 155-159.

Tyeb, A., Samad, M.A. and Paul, S.K. (2013). Growth of transplanted aman rice as affected by

variety and spacing. Bangladesh Journal of Environmental Science, 24:103-108.

UNDP and FAO. (1988). Land resources appraisal of Bangladesh for Agricultural Development, Report-2. Agroecological Regions of Bangladesh. BARC. UNDP. New Airport Road, Farmgate, Dhaka-1215. pp. 212-221. 